\title{
A ANÁLISE DA INCONSTITUCIONALIDADE DAS NORMAS NO PROCESSO ADMINISTRATTVO TRIBUTÁRIO
}

\author{
ALINE JACKISCH \\ Data da defesa: $12 / 12 / 2005$
}

\section{RESUMO}

Através do presente estudo, verificou-se a possibilidade de o Conselho de Contribuintes conhecer argüições de inconstitucionalidade no processo administrativo tributário. Isso, entretanto, não se confunde com a declaração de inconstitucionalidade, cujos efeitos são diferentes, e para o que o órgão julgador administrativo não tem competência por força dos arts. 97e 102, I, da Constituição Federal. Calse ao órgão administrativo julgador o controle da legalidade dos atos administrativos, o que também leva em conta a análise da conformidade das normas aplicadas no caso concreto à Constituição. Além disso, o Consellho não teria como desconhecer de argüições de inconstitucionalidade, em razão do princípio da ampla defesa, que obriga o órgão decisor a examinar todas as alegações trazidas pelo administrado, bem como a motivar a decisão administrativa. Entretanto, a verificação de constitucionalidade da norma aplicável ao ato administrativo não pode ser feita livremente, sob pena de violação ao princípio da separação de poderes. Isso deve ser feito, utilizando-se do postulado da interpretação conforme a Constituição, segundo a qual deve ser reconhecida a constitucionalidade da torma sempre que existir uma interpretação possivel neste sentido. Não sendo possível considerar a norma constitucional, por restar manifesta a inconstitucionalidade, não há como ser aplicada, sob pena de violação à Constituição. Assim,

: PROF, ORIENTADOR: Hurnberto Bergmann Ávila

BANCA EXAMINADORA:

Paulo Antônio Caliendo V. da Silveira PUCRS

Clándio Fortunato Michelon Junior UFRGS

Cezat Saldanha Souza Junior UFRGS 
verifica-se que as hipóteses em que poderia ser teconhecida a inconstitucionalidade da norma pelo Conselho de Contribuintes são mais amplas que aquelas previstas no art. $22 \mathrm{~A}$ do seu Regimento Interno, por observância ao princípio da ampla defesa, da eficiência administrativa, da juridicidade, da segurança juŕdica, sem, contudo violar-se o princípio da separação de poderes.

Palavras-chave: Conselho de Contribuintes; inconstitucionalidade; processo administrativo tributário. 